


\section{A KIERKEGAARD ANTHOLOGY}





\section{A \\ KIERKEGAARD \\ ANTHOLOGY \\ Edited by Robert Bretall}

PRINCETON UNIVERSITY PRESS

PRINCETON, NEW JERSEY 
COPYRIGHT 1946 BY PRINCETON UNIVERSITY PRESS

Philosophical Fragments, Copyright 1936, (C) 1962 by Princeton University Press; Stages on Life's Way, Copyright 1940 , (C) 1968 by Princeton University Press; Concluding Unscientific Postscript, Copyright 194I, (C) 1969 by Princeton University Press; The Sickness unto Death, Copyright 1941, 1954 by Princeton University Press; Repetition, Copyright 1941, (C) 1969 by Princeton University Press; Fear and Trembling, Copyright I94I, I954 by Princeton University Press; Attack upon "Christendom," Copyright 1944, (C) 1968 by Princeton University Press; Either/Or, Copyright 1944 by Princeton University Press, (C) 1972 by Howard A. Johnson; Works of Love, Copyright 1946 by Princeton University Press.

Copyright, 1943, by Augsburg Publishing House

Copyright, 1938, by Harper and Brothers

LC Card: $\mathrm{A}_{47-827}$

ISBN $0-69$ I-0 $978-9$ (paperback edn.)

ISBN 0-69r-07r96-9 (hardcover edn.)

First Princeton Paperback Edition, 1973

Princeton University Press books are printed on acid-free paper, and meet the guidelines for permanence and durability of the Committee on Production Guidelines for Book Longevity of the Council on Library Resources

http://pup.princeton.edu

PRINTED IN THE UNITED STATES OF AMERICA

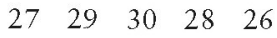

ISBN-13: 978-0-691-01978-9

ISBN-10: 0-691-01978-9 


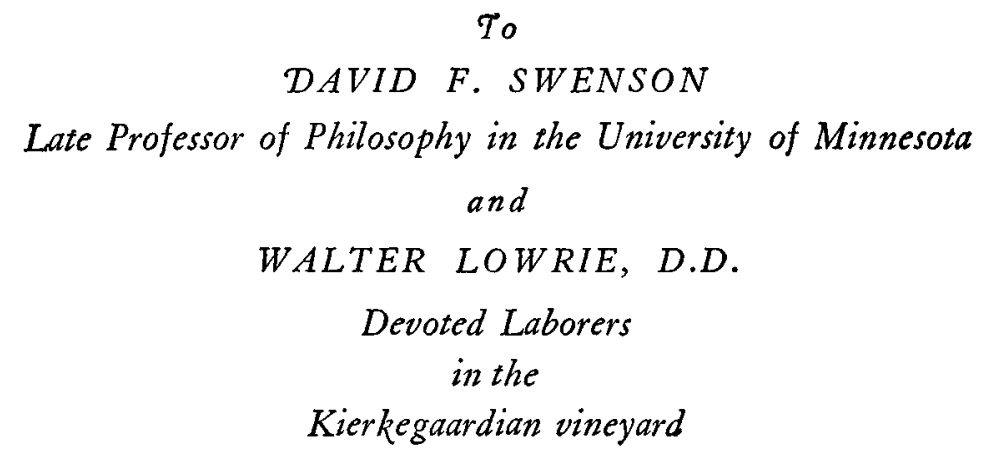


What is a poet? A poet is an unhappy being whose heart is torn by secret sufferings, but whose lips are so strangely formed that when the sighs and the cries escape them, they sound like beautiful music. His fate is like that of the unfortunate victims whom the tyrant Phalaris imprisoned in a brazen bull and slowly tortured over a steady fire; their cries could not reach the tyrant's ears so as to strike terror into his heart; when they reached his ears they sounded like sweet music. And men crowd about the poet and say to him: "Sing for us soon again"; that is as much as to say: "May new sufferings torment your soul, but may your lips be formed as before; for the cries would only frighten us, but the music is delicious." And the critics come, too, and say: "Quite correct, and so it ought to be according to the rules of aesthetics." Now it is understood that a critic resembles a poet to a hair; he only lacks the suffering in his heart and the music upon his lips. Lo, therefore, I would rather be a swineherd from Amager, and be understood by the swine, than be a poet and be misunderstood by men.-Either/Or

\section{“THE SACRIFICE," THE CORRECTIVE}

As a skillful cook says with regard to a dish in which already a great many ingredients are mingled: "It needs still just a little pinch of cinnamon" (and we perhaps could hardly tell by the taste that this little pinch of spice had entered into it, but she knew precisely why and precisely how it affected the taste of the whole mixture); as an artist says with a view to the color effect of a whole painting which is composed of many, many colors: "There and there, at that little point, there must be applied a little touch of red" (and we perhaps could hardly even discover that the red is there, so carefully has the artist suppressed it, although he knows exactly why it should be introduced). So it is with Governance.

$\mathrm{Oh}$, the Governance of the world is an immense housekeeping and a grandiose painting. Yet $\mathrm{He}$, the Master, God in heaven, behaves like the cook and the artist. $\mathrm{He}$ says: "Now there must be introduced a little pinch of spice, a little touch of red." We do not comprehend why, we are hardly aware of it, since that little bit is so thoroughly absorbed in the whole. But God knows why.

A little pinch of spice! That is to say: Here a man must be sacrificed, he is needed to impart a particular taste to the rest.

These are the correctives. It is a woeful error if he who is used for applying the corrective becomes impatient and would make the corrective normative for others. That is the temptation to bring everything to confusion.

A little pinch of spice! Humanly speaking, what a painful thing thus to be sacrificed, to be the little pinch of spice! But, on the other hand, God knows well him whom $\mathrm{He}$ elects to use in this way, and then He knows also how, in the inward understanding of it, to make it so blessed a thing for him to be sacrificed, that among the thousands of divers voices which express, each in its own way, the same thing, his also will be heard, and perhaps especially his which is truly de profundis, proclaiming: God is love. The birds on the branches, the lilies in the field, the deer in the forest, the fishes in the sea, countless hosts of happy men exultantly proclaim: God is love. But beneath all these sopranos, supporting them as it were, as the bass part does, is audible the de profundis which issues from the sacrificed one: God is love.-The Journals 